\title{
RELIGIJSKI IDENTITET MLADIH U REPUBLICI SRPSKOJ: VAŽNOST, PERCEPCIJA I MJERENJE
}

\begin{abstract}
Apstrakt
U ovom istraživanju pokušali smo detaljnije da ispitamo odnos mladih ka religijskom identitetu, ali na jedan obuhvatniji i precizniji način u odnosu na ranije. Ovaj cilj smo konkretizovali kroz nekoliko istraživačkih zadataka: 1) Pored opštih religijskih uvjerenja, ispitati i zastupljenost konkretnih religijskih manifestacija; 2) Ispitati percepciju karaktera religijskog identiteta; 3) Ispitati relacije različitih dimenzija religioznosti sa religioznom netolerancijom; 4) Ispitati važnost religioznosti u kontekstu drugih vrijednosnih orijentacija. Sprovedeno je istraživanje kvantitativnog tipa, na uzorku od 377 mladih (61.3\% djevojaka, 38.7\% mladića) iz Republike Srpske, prosječnog uzrasta od 19 godina. Upitnik je sadržavao pitanja o opštim i specifičnim religijskim manifestacijama, doživljaju religijskog identiteta, multidimenzionalnu skalu religioznosti, te skalu preferencije životnih stilova kojom je ispitivana važnost religioznosti u širem vrijednosnom kontekstu. Rezultati pokazuju da se većina mladih izjašnjava religiozno (71\%), ali da se u manjoj mjeri ispoljava kroz konkretne religijske aktivnosti. Za oko 92\% ispitanika religijski identitet je važan, a najčešće se ispoljava kroz obilježavanje vjerskih praznika, čin krštenja, te vođenje života po religijskim načelima. Postoji uvjerenje da se religijski identitet stiče rođenjem ili veoma rano, ali i da se se može mijenjati tokom života što ukazuje na složenu isprepletenost socijalizacijskog i primordijalnog pristupa u poimanju ovog identiteta. Koherentnost navedenih rezultata narušava podatak da je religioznost po važnosti rangirana na osmom mjestu u kontekstu drugih životnih stilova. Religiozna netolerancija korelira sa dimenzijama religiozna uvjerenja, religiozna praksa i tradicionalno-institucionalna religioznost. Rezultati su prodsikutovani u kontekstu relevantnih teorija i drugih srodnih istraživanja.
\end{abstract}

Ključne riječi: religijski identitet, religiozne dimenzije, netolerancija

\section{Uvod}

Religioznost se definiše na razne načine, ali uglavnom se u tim definicijama redovno spominje da je to organizovan sistem uvjerenja, ponašanja, rituala i simbola koji imaju za svrhu da pospješe bliskost sa svetim ili transcendentnim (Bog, viša sila, istina, realnost), te da pomognu većem razumijevanju i odgovornosti prema drugima s kojima živimo u zajednici (Koenig, McCullough, \& Larson, 2001). U

\footnotetext{
${ }^{1}$ Adresa autora: srdjan.dusanic@ff.unibl.org
} 
današnje vrijeme gotovo je uvriježen stav da je religioznost multidimenzionalna, koja podrazumjeva različite elemente i dimenzije poput vjere, religijskog ponašanja, iskustva, znanja, moralnog ponašanja itd. Začetnici ovavog pristupa, a sljedstveno tome i mjerenja su bili Glock i Stark (1968).

Kada govorimo o religijskom identitetu, on je pored religioznih uvjerenja zasnovan i na doživljaju pripadnosti određenoj religijskoj grupi. Može da ga generiše rađanje $u$ porodici određene vjeroispovijesti, formalno primanje u vjersku grupu (npr. kroz krštenje ili druge obrede), poznavanje i uvažavanje vjerskih doktrina određene vjerske grupe, poštovanje vjerskih praznika i običaja karakterističnih za tu grupu i slično. U većini slučajeva svijest o religijskoj pripadnosti stiče se rano, po nekim istraživanjima već u osmoj ili devetoj godini (Hyde, 1990). Utvrđeno je, takođe, da djeca prvo nauče svoj religijski identitet i uloge, a tek kasnije usvajaju vjeru, doktrine i rituale (Beit-Hallahmi \& Argyle, 1997). Priroda religijskog identiteta može se takođe razmatrati u kontekstu primordijalističke i socijalizacijske paradigme (Kaufmann, 2012). U primordijalističkom kontekstu socijalni identitet je fiksan i trajan, nepromjenjiv u toku života. On je čvrsta i trajna ljudska kategorija, data rođenjem, obojena iracionalnim i neizrecivim osjećanjima, koja vezuje ljude pradjedovskim porijeklom. U socijalizacijskoj paradigmi naglašava se instrumentalni i funkcionalni karakter kolektivnih identiteta, a to zavisi i od situacionih okolnosti. Religija je proizvod političkih, ekonomskih i istorijskih okolnosti, a bitna je za pojedinca i društvo u funkcionalnom i instrumentalnom kontekstu (Kaufmann, 2012; Milošević-Đorđević, 2005). Hogg i saradnici (Hogg, Adelman, \& Blagg, 2010) ističu da snaga religijske identifikacije leži između ostalog u činjenici da pruža ustaljen i utješan pogled na svijet, odbranu od straha od smrti, jak sistem socijalne podrške, osjećaj pripadnosti, a doprinosi i smanjenju nesigurnosti i nejasnoće u turbulentnim i tranzicijskim kontekstima.

Za vrijeme perioda socijalističkog društvenog uređenja u bivšoj Jugoslaviji, religija kao ideologija nije imala važnu i značajnu ulogu. Ispovjedanje vjere možda nije zabranjivano, ali svakako nije promovisano ili društveno „,nagrađivano“. Tako, Bahtijarević zaključuje da je sedamdesetih godina prošlog vijeka među mladima oko $1 / 3$ ateista, oko $1 / 3$ neopredijeljenih, te $1 / 3$ vjernika (Bahtijarević, 1975). Institut za društvena istraživanja Sveučilišta u Zagrebu 1985. godine je utvrdio da je oko 10\% mladih sa prostora bivše Socijalističke Federativne Republike Jugoslavije (SFRJ) išlo u crkvu (prema Pantić, 1988). Vrcan (1986) ističe da među zaposlenim u bivšoj Jugoslaviji dominiraju nereligiozni (oko 72\%), dok je religioznih 21\%, a neodlučnih 7\%. Pantić (1988) je ustanovio da je u Beogradu oko 3/4 osoba starijih od 15 godina nereligiozno. Isti autor zaključuje da je bio veliki trend pada religioznosti do sredine sedamdesetih godina, zatim je došlo do stagnacije, a poslije osamdesetih godina pojavili su se i znaci vjerske obnove.

Krajem 80-ih i početkom 90-ih godina prošlog vijeka dolazi do velikih društvenih promjena. Dolazi do pada višedecenijske vladavine socijalističkog sistema, te sukoba zasnovanih na etničkim i religijskim razlikama, koji dovode do raspada zajedničke države i stvaranja novih samostalnih država, uglavnom zasnovanih po etničkom principu. Snaženje etničkog identiteta je pratilo i snaženje religijskog 
identiteta i ta dva identiteta se praktično počinju poistovjećivati. Etnički identitet počinje praktično da određuje i odnose prema religiji. Tako se Hrvati izjašnjavaju kao katolici, Srbi kao pravoslavci, Bošnjaci kao muslimani (Dušanić, 2007a). Religija je postala sve zastupljenija i važnija u životima ljudi, ona postaje praktično socijalno - poželjna ideologija. To se manifestuje kroz popularizaciju u medijima, uvođenje vjerskog obrazovanja u škole, masovno građenje vjerskih objekata, vezu religije sa politikom itd. Dakle, uporedo sa osnaživanjem etničke svijesti i osjećanja dolazi i do ekspanzije religioznosti tako da je većina stanovništva počela da se izjašnjava kao religiozna (Dušanić, 2007b). Ove konstatacije potkrepljuju i brojna empirijska istraživanja, pogotovo sprovedena na prostorima Republike Srpske. U slučaju kada je religioznost mjerena jednim pitanjem sa ponuđenim višestrukim odgovorima, 69-89\% ispitanika se izjasnilo kao religiozno (npr. Dušanić 2013; Dušanić, Došen \& Tanasić, 2015;Tešanović, 2012; Turjačanin i sar., 2010). Kada se religioznost ispituje detaljnije, putem skala sa više tvrdnji ili pitanja, izraženost religioznosti je manja. Dušanić (2009) zaključuje da su opšta religijska uvjerenja u manjoj mjeri praćena konkretnim religijskim aktivnostima. Čini se da su ispitanici u tim istraživanjima skloni da se izjašnjavaju kao religiozni, ali to u daleko manjoj mjeri prate odgovarajući stavovi i ponašanja. To ukazuje na deklarativni karakter religioznosti kod velikog broja ispitanika, što je uslovljeno i socijalnom poželjnošću religije u društvu. Naime, religija je danas značajno prisutna u medijima, nosioci bitnih društvenih uloga se uglavnom izjašnjavaju kao religiozni, vjeronauka je dio redovnog školskog obrazovanja itd. Ambijent $u$ društvu je dakle takav, da postoji implicitan socijalni pritisak u smjeru većeg ispoljavanja religioznosti. Takva društvena klima može da determiniše ne samo religijske stavove pojedinca, već i njihov način izjašnjavanja tokom istraživačkog postupka, tj. može da se odrazi na socijalno poželjno odgovaranje, u smijeru ispoljavanja veće religioznosti nego što ona stvarno jeste. Ove tvrdnje potkrepljuju i istraživanja o vezi religioznosti i socijalno poželjnog odgovaranja. U istraživanju Subotića, Kneževića i Dimitrijevića (2014) potvrđena je socijalna poželjnost prilikom religijske samoidentifikacije ispitanika, a najviša je bila među kategorijama gnostičkih teista i gnostičkih ateista. Autori zaključuju da bi omnibus test izgubio statističku značajnost, potrebno bi bilo ukloniti $8.1 \%(p=.056)$, odnosno $18.2 \%$ ( $p$ $=.18$ ) ispitanika sa najvišim skorovima socijalne poželjnosti.

Jedan od izazova u istraživanjima je i veza religioznosti sa pojavama koje su u direktnoj ili indirektnoj vezi sa konfliktima, predrasudama, ratovima, terorizmom. Naime, ako se vodimo porukama iz vjerskih spisa koje ukazuju da je Bog ljubav, očekivali bismo da religiozni budu faktor tolerancije u društvu. Međutim, u Republici Srpskoj, ali i brojnim svjetskim istraživanjima, religiozni imaju veće predrasude i socijalne distance, izraženiji etnocentrizam itd. (npr. Beit-Hallahmi \& Argyle 1997; Dušanić, 2007c). Na osnovu tih rezultata postavlja se pitanje vjerske zrelosti stanovništva i javlja se potreba za pravljenjem distinkcije između različitih dimenzija religioznosti i tipova vjernika. Zbog sličnih razloga je još polovinom prošlog vijeka Allport pravio razliku između nezrele i zrele religioznosti (Allport \& Ross, 1967). Nezrelu karakteriše sklonost ka procjenjivanju drugih, samodovoljnost i preokupiranost sobom, nesaosjećajnost itd. Za razliku od nje ,zrelu“ religioznost karakteriše 
interes za ideale i vrijednosti a ne bazične potrebe, tolerancija, saosjećajnost, otvorenost ka drugima. Imajući ovo u vidu, te rezultate u Republici Srpskoj, jasno je da je i u našim istraživanjima neophodno uključiti različite dimenzije religioznosti, te vidjeti njihov efekat na različite društvene stavove. Međutim, neka ranija iskustva ukuzuju na to da je problem i u nedovoljnoj senzitivnosti ili neprilagođenosti postojećih instrumenata. Tako npr. u istraživanju Dušanića $(2007 \mathrm{c})$, utvrđene su slične veze (a što nije u skladu sa hipotezama i inostranim istraživanjima) intrinzičke, ekstrinzičke i fundamentalne religioznosti sa socijalnim distancama, stavovima prema ratu itd.

Sve navedeno ukazuje da je odnos ljudi u Republici Srpskoj prema religioznosti prilično kompleksan te determinisan i brojnim socijalnim faktorima koji mogu da utiču na vjerodostojnost dobijenih rezultata. To ukazuje na potrebu za senzitivnijim ispitivanjem religioznosti, što podrazumjeva korištenje različitih načina mjerenja religioznosti, ali i ispitivanje nekih aspekata religioznosti koji su do sada bili zapostavljeni.

U ovom istraživanju smo pokušali da dopunimo dosadašnje rezultate tako što smo detaljnije ispitali različite aspekte odnosa prema religiji, ali i važnost religioznosti iz nekih drugačijih perspektiva. Ovo smo formulisali u vidu nekoliko istraživačkih zadataka: 1) pored opštih religijskih uvjerenja, ispitati zastupljenost i konkretnijih religijskih manifestacija, uvjerenja, znanja i ponašanja; 2) ispitati prirodu religijskog identiteta, kako i kada se on stvara i razvija, kako se ispoljava, kako ga mladi poimaju, kakav je odnos sa etničkim identitetom; 3) ispitati u kakvim su relacijama različite dimenzije religioznosti (npr. religijska uvjerenja, ponašanja, znanje, iskustvo itd.) sa religijskom netolerancijom i 4) razmotriti važnost religioznosti u kontekstu drugih vrijednosnih orijentacija (npr. saznajni, utilitarni, porodični, hedonistički, moć, popularnost, altruistični, egoistični, promejtejski) jer na taj način se objektivnije može ispitati važnost religijskih uvjerenja te interpretirati eventualne nedosljednosti u odnosima sa drugim pojavama.

\section{Metod}

\section{Uzorak i procedura}

Sprovedeno je istraživanje kvantitativno-kvalitativnog tipa, na uzorku od 377 mladih (61.3\% djevojaka, 38.7\% mladića) iz Republike Srpske. Prikupljanje podataka je najvećim dijelom izvršeno u banjalučkoj regiji, pri čemu treba imati u vidu da su brojni ispitanici koji pohađaju fakultete u Banjaluci, porijeklom iz raznih opština Republike Srpske. Prosječni uzrast je bio 19 godina (raspon godina 16-24). 95\% ispitanika je bilo srpske nacionalnosti, 2.4\% Bošnjaka, 1.1\% Hrvata i 1.6\% ostalih. Na pitanje o vjeroispovijesti, 92\% se izjasnilo kao pravoslavci, 0.8\% kao katolici, $2.4 \%$ muslimani, a $4 \%$ se izjasnilo kao nereligiozno.

Ispitanici su istraživanju pristupili dobrovoljno, a upitnik su popunjavali anonimno. Popunjavanje upitnika je vršeno metodom papir - olovka, a odvijalo se u ve- 
ćini slučajeva u grupama, u srednjim školama i fakultetima. Tokom istraživanja nisu zabilježeni problemi u smislu da su ispitanici negodovali zbog sprovođenja istraživanja ili zbog nekih konkretnih pitanja.

\section{Instrumenti}

$\mathrm{Na}$ početku upitnika, pored pitanja o sociodemografskim karkateristikama ispitanika, postavljeno je i nekoliko pitanja koje obuhvatamo nazivom ,percepcija religijskog identiteta“. Set ovih pitanja je krerian za potrebe ovog istraživanja od strane autora a odnosio se na to: kada su ispitanici postali svjesni svog religioznog identiteta, kako se on stiče/dobija, koliko im je to važno, da li svi ljudi moraju da ga imaju, kako se ispoljava privrženost ovom identitetu, mogu li da ga mijenjaju, kakav je odnos njihovog i drugih religijskih identiteta, odnos religijskog i etničkog identiteta itd.

Sa svrhom senzibilnijeg mjerenja religioznosti primjenjena je i Multidimenzionalna skala religioznosti Likertovog tipa (raspon od jedan do pet) koju je kreirao autor ovog istraživanja. Skala je kreirana na osnovu uvažavanja dominantnih multidimenzionalnih pristupa religioznosti u ovoj oblasti koji najčešće podrazumjevaju postojanje dimenzija religijskih uvjerenja, aktivnosti, znanja, iskustva. Jedan od takvih pristupa je od Glocka i Starka (1968), potom Cornwala i saradnika (Cornwall, Albrecht, Cunningham, Pitcher, 1986 ) itd. Pored toga, analizom preko 140 različitih upitnika (od kojih je značajan dio predstavljen u knjizi „Measures of religiosity“; Hill \& Hood, 1999), krerian je širi set pitanja i tvrdnji koje smo uključili u preliminarnu verziju sadašnjeg upitnika. Ta verzija je provjeravana kroz višegodišnje eksperimentisanje pri čemu su se brojni indikatori pokazali nedovoljno senzibilnim, o čemu je nešto rečeno i u uvodu (Dušanić, 2007b).

Analizom glavnih komponenti uz Promaks rotaciju identifikovano je sedam faktora koji mjere dimenzije religijskih uvjerenja, aktivnosti, iskustva i znanja, te altruistične religioznosti, tradicionalno-institucionalne religioznosti i religijske netolerancije. Ovim faktorima je ukupno objašnjeno oko $62 \%$ varijanse (više detalja u prilogu). Pouzdanost podskala izražena preko koeficijenta Cronbach alpha je zadovoljavajuća, pogotovo imajući u vidu da su podskale obuhvatale relativno mali broj tvrdnji, od četiri do sedam. Mali broj tvrdnji po podskalama je posljedica težnje za što ekonomičnijim instrumentom, a i neke tvrdnje su odbačene jer su remetile pouzdanost instrumenata. Pouzdanost je varirala od .70 do .88 . Više detalja o ovim podskalama je dato u narednoj tabeli.

Tabela 1

Prikaz podskala religioznosti

\begin{tabular}{llcc}
\hline Podskala & Primjer tvrdnje/pitanja & $\begin{array}{c}\text { Broj } \\
\text { tvrdnji }\end{array}$ & Pouzdanost \\
\hline Rel. uvjerenja & $\begin{array}{l}\text { Vjerujem da postoji Bog. } \\
\text { Koliko često ideš u bogomolju } \\
\text { da bi prisustvovao/la vjerskim } \\
\text { obredima? }\end{array}$ & 5 & .85 \\
&
\end{tabular}




$\begin{array}{llll}\text { Rel.iskustva } & \begin{array}{l}\text { Imao/la sam doživljaj Božjeg } \\ \text { prisustva i njegove energije. }\end{array} & 7 & .88 \\ \text { Rel.znanje } & \begin{array}{l}\text { Koliko ukupno ima jevanđelja? } \\ \text { Moj odnos prema vjeri i Bogu, }\end{array} & 4 & .70 \\ \text { Altruistična } & \begin{array}{l}\text { utiče da činim dobro i onima } \\ \text { koji me mrze. }\end{array} & 5 & .88 \\ \text { Vjernik sam jer tako potvrđujem } & & .83 \\ \text { institucionalna rel. } & \begin{array}{l}\text { i štitim i svoj nacionalni } \\ \text { identitet. } \\ \text { Ne bih volio/la da moja djeca } \\ \text { idu u razred sa djecom drugih } \\ \text { religija. }\end{array} & 5 & .77 \\ \text { Rel. netolerancija } & & 5 & \\ & \end{array}$

Skala preferencije životnih stilova (The Study of Values - SOV; Allport, Vernon, \& Lindsey, 1960, adaptirao Popadić, 1995). Skala ima uporište u Šprangerovoj tipologiji vrijednosti. Pojam stil života određuje se preko načina provođenja slobodnog vremena, načina zadovoljenja potreba, karakterističnih interpersonalnih i društvenih odnosa koje pojedinac uspostavlja i u koje ulazi. Skala mjeri važnost različitih životnih stilova kao što su: religijski, saznajni, utilitarni, porodični, hedonistički, moć, popularnost, altruistični, egoistični, prometejski. U skali su preizno opisani navedni životni stilovi, a trebalo je da ispitanici rangiraju od 1 do 10 preferiranje pojedinačnih stilova. Na osnovu vrednovanja važnosti tih stilova možemo uočiti koju poziciju religija zauzima i u širem vrijednosnom sistemu ispitanika.

\section{Rezultati}

\section{Zastupljenost religioznosti}

U početku ćemo predstaviti nekoliko tabela koje ukazuju na odnos ispitanika prema religiji.

Tabela 2

Samoprocjena religioznosti

\begin{tabular}{lc}
\hline Opšta procjena religioznosti & $\%$ \\
\hline definitivno nisam religiozan/na & 2.4 \\
nisam religiozan/na & 6.9 \\
nisam siguran/na & 19.9 \\
religiozan/na sam & 60.2 \\
veoma sam religiozan/na & 10.6 \\
\hline Ukupno & 100.0 \\
\hline
\end{tabular}


Tabela 3

Odnos ispitanika prema religioznosti

\begin{tabular}{|c|c|}
\hline Tipovi religioznih & $\%$ \\
\hline Nikada nisam vjerovao/la u Boga ili u kakvu višu silu & .5 \\
\hline $\begin{array}{l}\text { Postojanje Boga se ne može dokazati i zato ne želim da tvrdim da Bog } \\
\text { postoji ili ne postoji }\end{array}$ & 6.9 \\
\hline $\begin{array}{l}\text { Nekada vjerujem u Boga, a nekada mi se dešava da ne vjerujem i da } \\
\text { sumnjam u njegovo postojanje }\end{array}$ & 8.5 \\
\hline Prihvatam svoju religijsku pripadnost ali ne vjerujem u Boga & 2.9 \\
\hline $\begin{array}{l}\text { Ne vjerujem u Boga već vjerujem u neku višu nadnaravnu silu ili } \\
\text { energiju koja prožima svemir }\end{array}$ & 4.9 \\
\hline $\begin{array}{l}\text { Vjerujem u Boga i u vjerske istine koje nam se otkrivaju kroz poruke } \\
\text { vjerskih lica }\end{array}$ & 45.1 \\
\hline Vjerujem u Boga, ali nemam u povjerenja u vjerska lica & 31.6 \\
\hline Ukupno & 100.0 \\
\hline
\end{tabular}

Iz tabele 2 vidimo da se oko $71 \%$ ispitanika izjašnjava kao religiozno. U trećoj tabeli vidimo da među vjernicima postoji $45 \%$ vjernika koji podržavaju rad vjerskih lica, dok značajan broj (31.6\%) nema povjerenje u vjerska lica. Oko 16\% ispitanika ispoljava nepostojan odnos prema religiji dok oko $4.5 \%$ bi se moglo svrstati u kategoriju spiritualista koji vjeruju u neku energiju, ali je ne zovu Bog. Oko 3\% ispitanika prihvata svoju religijsku pripadnost, ali ne vjeruje u Boga.

Tabela 4

Zastupljenost različitih dimenzija religioznosti

\begin{tabular}{lrrrr}
\hline Dimenzije religioznosti & \multicolumn{1}{c}{ Min } & \multicolumn{1}{c}{ Max } & \multicolumn{1}{c}{$S D$} \\
\hline Religijska uvjerenja & 1.00 & 5.00 & 4.02 & .87 \\
Religijske aktivnosti & 1.00 & 5.00 & 2.66 & .72 \\
Religiozno iskustvo & 1.00 & 5.00 & 2.74 & .91 \\
Religijsko znanje & .00 & 1.00 & .47 & .25 \\
Religijska netolerancija & 1.00 & 5.00 & 1.38 & .83 \\
Tradicionalno- & 1.00 & 5.00 & 3.38 & .88 \\
institucionalna religioznost & & & 3.19 & 1.04 \\
Altruistična religioznost & 1.00 & 5.00 & 3.19 \\
\hline
\end{tabular}

U dodatnim analizama smo poredili navedene dimenzije obzirom na pol. Ustanovljena je samo jedna značajna razlika, kod mladića je značajno više bila izražena religiozna netolerancija nego kod djevojaka $(t(369)=-3.371 ; p<.01)$, a u ostalim dimenzijama nije bilo razlika (detalji analize u prilogu 2). 
Tabela 5

Zastupljenost specifičnih religioznih aktivnosti

\begin{tabular}{lc}
\hline Religiozne aktivnosti & $\%$ \\
\hline Posjećivali bogomolju u zadnjih mjesec dana & 42.6 \\
Molitva u zadnjih 7 dana & 62.2 \\
Čitao/la vjerske knjige u zadnjih mjesec dana & 15.8 \\
Znanje o broju Jevanđelja u Novom zavjetu & 57.6 \\
\hline
\end{tabular}

U tabeli 5 vidimo nivo praktikovanja nekih standardnih religijskih aktivnosti. Oko $62 \%$ ispitanika praktikuje molitvu barem jednom sedmično, a $42 \%$ posjeti bogomolju tokom mjeseca. Najmanji procenat ispitanika (oko 16\%) upražnjava svoju religioznost kroz čitanje vjerskih knjiga (makar jednom mjesečno). Ilustracije radi, čak $42.4 \%$ ispitanika nije znalo koliko u Novom zavjetu ima jevanđelja. Smatramo da je to veliki procenat, budući da se radi o bazičnoj informaciji iz ključnog hrišćanskog spisa.

\section{Religijski identitet}

Postavili smo ispitanicima nekoliko pitanja koja se odnose na prirodu njihovog religijskog identiteta. Na sažet način ćemo pokušati predstaviti neke osnovne nalaze.

Većina ispitanika ističe da im je religijska pripadnost važna. Za $48.5 \%$ je to jako važno, a za $43.7 \%$ srednje važno. Samo za $7.7 \%$ ispitanika je religijska pripadnost nevažna. Ovi rezultati su kompatibilni ranije navedenim samoprocjenama religioznosti (npr. Dušanić, 2007 b).

Oko $77 \%$ ispitanika je istaklo da su svoje religijske pripadnosti postali svjesni kao jako mali, 11\% među vršnjacima, a oko $9 \%$ tek kad su odrasli.

Ispitanicima je postavljeno i pitanje otvorenog tipa kako se postaje član određene vjeroispovijesti. Dobili smo ukupno 233 odgovora. Izvšena je kvalitativna analiza odgovora te njihovo svrstavanje u određene kategorije, njih pet, te kategorija ostali. U narednoj tabeli predstavljamo intenzitet zastupljenosti tih kategorija, te po jedan citat kao ilustraciju svake kategorije.

Tabela 6

Kategorizacija odgovora na pitanje otvorenog tipa: Kako se postaje član određene vjeroispovijesti?

\begin{tabular}{llc}
\hline Kategorije & Primjer & $\%$ \\
\hline Rođenje & „Samim rođenjem postajemo pripadnikom određene religije“ & 27.0 \\
Krštenje & „Krštenjem ili drugim obredom pristupanja“ & 26.6 \\
Uticaj roditelja & „Vaspitanjem u porodici, slušajući roditelje“ & 24.5 \\
Kroz religijske & „Čitanjem religijskih spisa, poštovanjem obreda, & 10.3 \\
aktivnosti & posjećivanjem bogomolja“ & 7.3 \\
Sopstveni izbor & „Kroz lična ubjeđenja“ & 4.3 \\
\hline Ostalo & Npr: „,Kriva je vjeronauka“ & 100.0 \\
\hline Ukupno & & \\
\hline
\end{tabular}


U ovim kategorijama vidimo da su pripadnost vjeroispovijesti ispitanici objašnjavali rađanjem u određenoj porodici, uticajem porodice, činom krštenja, konkretnim religijskim aktivnostima, sopstvenim izborom. Najveći broj ispitanika je pripadnost vjeroispovijesti objašnjavao putem rođenja $u$ određenoj porodici ili obrednim činom krštenja, a značajna uloga je data i roditeljima. Na navedene rezultate se nadovezuju odgovori na još neka srodna pitanja o percepciji religijskog identiteta.

\section{Tabela 7}

Stavovi o prirodi religijskog identiteta

\begin{tabular}{lc}
\hline Pitanja & $\%(\mathrm{da})$ \\
\hline Da li svi ljudi moraju da spadaju u neku religiju? & 85.9 \\
$\begin{array}{l}\text { Da li osoba može mijenjati to kojoj religiji pripada? } \\
\text { Da li osoba može biti istovremeno pripadnik dvije religije? }\end{array}$ & 90.5 \\
$\begin{array}{l}\text { Da li su pripadnici tvoje religije mnogo sličniji tebi, nego pripadnici } \\
\text { drugih religija? }\end{array}$ & 72.3 \\
$\begin{array}{l}\text { Da li se pripadnici tvoje religije mnogo razlikuju od pripadnika drugih } \\
\text { religija? }\end{array}$ & 78.9 \\
\hline
\end{tabular}

Rezultati iz ove tabele su takođe raznovrsni i ukazuju da među mladima ne postoji dosljedna percepcija prirode religijskog identiteta. Oko 86\% smatra da svi ljudi moraju da spadaju u neku religiju, što implicira primordijalno poimanje, ali sa druge strane veliki procenat smatra da se taj izbor može mijenjati $(90.5 \%)$, te da osoba istovremeno može biti pripadnik dvije religije (72.3\%). Pored ovih karakteristika vidimo da ispitanici (njih oko 80\%) percipiraju veliku unutargrupnu sličnost te međugrupne razlike.

Tabela 8

Vidovi ispoljavanja religijskog identiteta

\begin{tabular}{lc}
\hline Važnost određenih aktivnosti za ispoljavanje religijskog identiteta & $\%$ \\
\hline Čuvanje običaja i tradicije & 83.2 \\
Obilježavanje vjerskih praznika & 81.0 \\
Krštenje & 76.7 \\
Ljubav prema drugim ljudima & 76.6 \\
Moralan život po Božijim zapovjestima & 74.2 \\
Redovna molitva & 69.2 \\
Post & 63.1 \\
Posjećivanje bogomolja & 55.6 \\
Popis stanovništva & 42.1 \\
Kroz spremnost da se ako treba i ratuje za očuvanje svoje religije & 37.8 \\
Nošenje religijskog ukrasa/ simbola & 25.9 \\
Verbalno izjašnjavanje & 23.1 \\
\hline
\end{tabular}

U ovoj tabeli (tabeli br. 8) vidimo u kojoj mjeri su navedene stavke važne ili veoma važne za ispoljavanje sopstvenog religijskog identiteta. Većina ispitani- 
ka je 2/3 navedenih aktivnosti ocijenila kao važne u tom kontekstu. Izdavajaju se tri srodne grupe najvažnijih elemenata religijske identifikacije. Vidimo da najviše dominiraju (77\%-83\%) aktivnosti koje se odnose na praktikovanje tradicionalnih manifestacija religije poput vjerskih praznika, običaja i krštenja. Nakon toga slijedi vođenje života po određenim religijskim i moralnim načelima (74\%-77\%). Treća komponenta aktivnosti se odnosi na religijske aktivnosti poput molitve, posta, posjećivanja bogomolja (55\%-69\%). Nešto manju važnost (23\%-42\%) imaju aktivnosti koje se odnose na deklarativno ispoljavanje religijske pripadnosti kroz verbalno izjašnjavanje, izjašnjavanje pri popisu stanovništva, nošenje religiozbnih simbola u vidu nakita itd. Ispitanici su nešto niže ocijenili i sklonost oružane borbe zarad očuvanja religijskog identiteta.

Tabela 9

Percepcija odnosa etničke i religijske pripadnosti

\begin{tabular}{lc}
\hline Kakav je po tebi odnos pripadnosti naciji i religiji ? & \% \\
\hline Pripadnost naciji utiče na to koje ću biti religije & 26.8 \\
Pripadnost religiji utiče na to koje ću biti nacije. & 14.6 \\
Religija i nacija su potpuno različiti pojmovi i nezavisni jedno od drugog. & 58.5 \\
\hline Ukupno & 100.0 \\
\hline
\end{tabular}

Budući da na balkanskim prostorima često dolazi do izjednačavanja religijske i etničke pripadnosti (npr. Runić, 2011), postavili smo ispitanicima i pitanje o odnosu ova dva socijalna identiteta (tabela br. 9). Blizu 60\% ispitanika smatra da su to različite pojave, oko $27 \%$ da pripadnost naciji utiče na religijsku pripadnost, a blizu $15 \%$ da je religijska pripadnost odrednica nacionalne. Dakle, preko $40 \%$ ispitanika ima pogrešna poimanja i interpretacije o odnosu religijskog i etničkog identiteta, smatrajući ih uzajamno zavisnim.

Tabela 10

Važnost religioznosti u širem vrijednosnom kontekstu

\begin{tabular}{lc}
\hline Životni stilovi & $\begin{array}{c}\text { Rang } \\
\text { važnosti }\end{array}$ \\
\hline Upoznati osobu koju voliš, zajedno sa njom osnovati porodicu ... Porodični & 1 \\
Baviti se nečim što je korisno za ljude. Pomagati ljudima ... Altruistični & 2 \\
Starati se prije svega o sebi i svojoj dobrobiti... Egoistični & 3 \\
Baviti se dobro plaćenim poslom koji će mi donijeti puno para ... Utilitarni & 4 \\
Baviti se istraživanjima, tragati za novim otkrićima... Saznajni & 5 \\
Život proživjeti što bezbrižnije i veselije. Lepo se zabavljati... Hedonizam & 6 \\
Uporno se zalagati za stvaranje boljih i pravednijih odnosa u svojoj okolini i & 7 \\
društvu... Prometejski & 8 \\
Vjerovati u Boga i živjeti u skladu sa učenjem svoje vjere... Religijski & 9 \\
Zauzimati neki rukovodeći položaj u društvu. Imati veliku moć... Moć & 10 \\
Postati popularan, biti poznat u sportu, muzici, zabavi... Popularnost & \\
\hline
\end{tabular}


U ovom istraživanju smo pokušali da visoke skorove o važnosti religoznosti i religijskog identiteta provjerimo iz još jednog ugla. Ispitanicima je predočeno 10 životih stilova i od njih je traženo da ih rangiraju po važnosti od 1 do 10 . Kao najvažniji su se pokazali porodični životni stil, altruistični, egoistični, utilitarni, saznajni itd. Zanimljivo je da je u kontekstu ovih orijentacija na osnovu prosječnog ranga važnost religioznog životnog stila tek na osmom mjestu. Dakle, većina ljudi je možda religiozna, ali čini se da religioznost u kontekstu drugih životnih stilova ne zauzima primarnu i centralnu poziciju.

\section{Relacije religiozne netolerancije i dimenzija religioznosti}

Tabela 11

Percepcija važnosti sopstvene i drugih religija

\begin{tabular}{lc}
\hline Kakav je po tebi odnos tvoje i drugih religija ? & $\mathbf{\%}$ \\
\hline Moja religija je manje vrijedna & 1.1 \\
Jednako su vrijedne & 79.9 \\
Moja religija je bolja od drugih & 19.0 \\
\hline Ukupno & 100.0 \\
\hline
\end{tabular}

Tabela pokazuje da skoro svaka peta anketirana osoba smatra da je njihova religija bolja od drugih dok $80 \%$ smatra da su jednako vrijedne. Ovo ukazuje na djelimičnu prisutnost fenomena unutargrupne favorizacije i međugrupnog rivaliteta.

Tabela 12

Povezanost religiozne netolerancije $i$ drugih dimenzija religioznosti

\begin{tabular}{lcccccc}
\hline & $\begin{array}{c}\text { Rel. } \\
\text { uvjerenja }\end{array}$ & $\begin{array}{c}\text { Rel. } \\
\text { aktivnosti }\end{array}$ & $\begin{array}{c}\text { Rel. } \\
\text { iskustvo }\end{array}$ & $\begin{array}{c}\text { Rel. } \\
\text { znanje }\end{array}$ & $\begin{array}{c}\text { Altruistična } \\
\text { rel. }\end{array}$ & $\begin{array}{c}\text { Tradic.-instit. } \\
\text { rel. }\end{array}$ \\
\cline { 2 - 7 } $\begin{array}{l}\text { Rel. } \\
\text { netolerancija }\end{array}$ & $.163^{* *}$ & $.193^{* *}$ & $.145^{* *}$ & -.001 & -.003 & $.315^{* *}$ \\
\hline
\end{tabular}

$* * p<.01$

Prethodne navode o religijskoj pristrasnosti i rivalitetu smo pokušali detaljnije obraditi kroz vezu religioznih dimenzija sa religioznom netolerancijom. Paradoksalno, ali ne i iznenađujuće, četiri dimenzije (religiozna uvjerenja, aktivnosti, iskustvo i tradicionalno-institucionalna religioznost) koreliraju sa religioznom netolerancijom. Korelacije su bile niske $i$ varirale su do $r_{\max }=.315$. Tri preostale dimenzije (znanje, altruistična religioznost) nisu u značajnoj korelaciji sa netolerancijom. Dakle, čini se da u ovom slučaju religiozna netolerancija više korelira sa konvencionalnim vidovima religioznosti, a manje sa dimenzijama koje podrazumjevaju veću posvećenost, iskrenost i vjersku zrelost. 


\section{Diskusija}

Možemo zaključiti da i ovo istraživanje pokazuje da se većina mladih iz Republike Srpske izjašnjava kao religiozno (71\%) što je bio slučaj i u brojnim drugim istraživanjima (npr. Dušanić 2013; Dušanić i sar., 2015; Tešanović, 2012; Turjačanin i sar., 2010). Detaljnija analiza ukazuje i da su generalna religijska uvjerenja u manjoj mjeri ispraćena konkretnim religijskim ponašanjima kao što su religijska praksa, znanje itd. Ljudi na prostorima Republike Srpske i Bosne i Hercegovine u većoj mjeri verbalno ispoljavaju svoju religioznost nego što to praktikuju kroz molitvu, posjećivanje bogomolja, čitanje vjerske literature. Takođe, rezultati ukazuju da postoji značajan prostor da religijske institucije unaprijede svoj rad i imidž u društvu budući da značajan dio ispitanog uzorka ne podržava njihovo djelovanje. U ovom istraživanju se ponovo pokazalo i da među mladićima i djevojkama u Republici Srpskoj ne postoji mnogo razlika u religioznosti, za razliku od rezultata u istraživanjima sa odraslim osobama (npr. Dušanić, 2009) te generalno inostranim istraživanjima. Ovo je u skladu sa rezultatima iz nekoliko istraživanja (npr. sumirano u Dušanić, 2007b) koja ukazuju da na religioznost mladih moguće da utiču neki opštiji socijalizacijski faktori, kao što je npr. proreligioznost kompletne kulture, i koji „poklapaju“ uticaj specifičnijih faktora poput pola, obrazovanja, finansijskog statusa i sl.

Za većinu ispitanika religijski identitet je važan, a većina ga je postala svjesna još u djetinjstvu. Među mladima ne postoji dosljedna i istovjetna percepcija prirode religijskog identiteta, te ukoliko razmatramo ove rezultate u kontekstu primordijalnog i socijalizacijskog pristupa, možemo zaključiti da su u odgovorima naših ispitanika oba zastupljena. Većina ispitanika istovremeno smatra da svi ljudi moraju da spadaju u neku religiju, ali i da se taj izbor može mijenjati, te da osoba istovremeno može biti pripadnik dvije religije. Ispitanici su svjesni promjenljivog karaktera i socijalizacijskog aspekta religijskog identiteta, ali rijetko možemo u stvarnosti primjetiti da su ljudi mijenjali svoj religijski identitet. Neki smatraju da je reigijski identitet pripadnost definisana rođenjem i porijeklom, dok drugi ukazuju na ulogu nekih situacionih okolnosti kao što je uticaj roditelja, izbor i aktivnosti pojedinca. Ovakav doživljaj religijskog identiteta najbliži je konceptu konstruisanog primordijalizma. Dakle, postoji uvjerenje da se religijski identitet stiče rođenjem ili veoma rano, ali i da se može mijenjati tokom života (Kaufmann, 2012). Blizu 60\% ispitanika doživljava religijski i etnički identitet kao nezavisne, dok ostali smatraju da su uzajamno uslovljeni. Navedeni rezultati su slični onima koje je dobio i Runić (2011), takođe na uzorku u Republici Srpskoj. Ispitanici su na informativnom nivou svjesni "autonomije" vjeroispovijesti i etniciteta, ali čini se da ih na emocionalnom planu doživljavaju kao veoma bliske komponente svog identiteta. Pored toga, većina ispitanika percipira veliku unutargrupnu sličnost te međugrupne razlike. Ovo je vjerovatno posljedica fenomena „optimalne različitosti“ (Turjačanin, 2015). Ljudi pored potrebe za pripadnošću određenoj grupi, ispoljavaju i tendencije da budu različiti od ostalih grupa, čime je zadovoljena potreba za posebnošću sopstvenog socijalnog identiteta, a samim tim i samopoštovanja. 
Značaj religioznosti smo ispitivali i u kontekstu drugih vrijednosnih i životnih stilova, a interesantno je da je važnost religoznog stila života rangirana tek na osmom mjestu. Ovaj podatak je vrijedan jer može doprinijeti objašnjenju nekih paradoksalnih rezultata u istraživanjima. Dakle, većina ljudi je možda religiozna, ali čini se da religioznost u njihovom vrijednosnom sistemu ne zauzima primarnu i centralnu poziciju. Kroz ovo možemo razumjeti i zašto u praksi i istraživanjima uočavamo uključenost religioznih u razne aktivosti koje su suprotne religioznim normama. U diskutabilnim situacijama i moralnim dilemama, zbog veće važnosti nekih drugih orijentacija, religiozne osobe će iako su religiozne, posegnuti možda za drugim rješenjima koja će doprinijeti ostvarivanju nekih za njih važnijih ciljeva (npr. porodični komoditet, hedonizam, neke druge egoistične ili intelektualne potrebe itd). Dakle, u određenim situacijama prevladaće vrijednosti i životni stilovi koji su za dotičnu osobu dominantniji i primarniji od religioznosti.

Kompleksnu sliku o religioznosti mladih nadopunjavaju podaci o zastupljenosti i korelatima religiozne netolerancije. Religiozna netolerancija kao dimenzija nije bila tako visoko izražena, a ovome ide u prilog i podatak da je kod $80 \%$ ispitanika bilo izraženo uvjerenje o jednakoj vrijednosti različitih religija. Dimenzije religiozna uvjerenja, religiozna praksa, iskustvo i tradicionalno-institucionalna religioznost koreliraju sa religioznom netolerancijom, dok ne postoji veza sa religioznim znanjem i altruističnom religioznošću. Ovaj podatak je takođe vrijedan jer daje određene smjernice koje dimenzije mogu biti korelat društvenog uravnoteživanja, a koje problematizuju odnose. U našem slučaju religiozna netolerancija više korelira sa konvencionalnim vidovima religioznosti, a manje sa dimenzijama koje podrazumjevaju veću posvećenost, iskrenost i vjersku zrelost.

\section{Zaključak}

Kroz ovo istraživanje pokušali smo detaljnije i na više načina ispitati različite aspekte religijskog identiteta i uvjerenja mladih u Republici Srpskoj.

Dobijeni rezultati su upotpunili mozaik znanja o religijskom identitetu, ali i ukazali da rezultate o uvriježeno velikoj važnosti i zastupljenosti religioznosti među mladima u Republici Srpskoj treba uzeti i sa rezervom. Religioznost je u većoj mjeri zastupljena na deklarativnom nivou nego kroz neke konkretne aktivnosti, a u kontekstu drugih životnih stilova takođe nema primarnu važnost i centralnu poziciju. Poimanje religijskog identiteta je takođe rezultanta isprepletenosti socijalizacijskih i primordijalnih principa. Sve ovo ukazuje i na nedovoljnu neizdiferenciranost religioznosti unutar ličnosti mladih u Repubici Srpskoj, što je i simptom tzv. nezrele religioznosti (Allport \& Ross, 1967). Ovi uvidi olakšavaju razumjevanje i interpetaciju nekih rezultata, pogotovo onih koji povezuju religioznost (u našem istraživanju pogotovo konvencionalne vidove religioznosti) sa određenim problematičnim pojavama poput predrasuda, etničkih distanci itd.

Sve ovo nam ukazuje na potrebu korištenja različitih načina mjerenja religioznosti da bi rezultati bili što realniji i potpuniji. Potrebno je pored opštih religijskih 
uvjerenja, mjeriti i konkretne religijske manifestacije, te važnost religioznosti u kontekstu ukupnog vrijednosnog sistema osobe. U budućnosti bi imalo smisla srodna istraživanja uraditi na još većem i raznovrsnijem uzorku, među drugim religijama, te uključiti još neke dodatne varijable kao što je npr. socijalno poželjno odgovaranje. Potraga za „svetim gralom“ u oblasti psihologije religije, tj. suštinom religioznosti i kako je mjeriti, očigledno će se i dalje nastaviti.

\section{Reference}

Allport, G. W., \& Ross, J. M. (1967). Personal religious orientation and prejudice. Journal of Personality and Social Psychology, 5(4), 432-443.

Allport, G. W, Vernon, P. E., \& Lindzey, G. (1960). Study of values: Manual and test booklet (3rd ed.). Boston, MA: Houghton Mifflin.

Bahtijarević, Š. (1975). Religijsko pripadanje u uvjetima sekularizacije društva. Zagreb: Narodno sveučilište grada Zagreba, Centar za aktualni politički studij.

Beit-Hallahmi, B., \& Argyle, M. (1997). The psychology of religious behaviour, belief, and experience. New York, NY: Routledge.

Cornwall, M., Albrecht, S. L., Cunningham, P. H., \& Pitcher, B. L. (1986). The dimensions of religiosity: A conceptual model with an empirical test. Review of Religious Research, 226-244.

Dušanić, S. (2013). Religioznost i određeni korelati mentalnog zdravlja mladih. Godišnjak za psihologiju, 9(11), 57-67.

Dušanić, S. (2009). Porodica i religioznost. Banjaluka: Centar za kulturni i socijalni popravak.

Dušanić, S. (2007a). Religiozna orijentacija i naučena bespomoćnost adolescenata. Banjaluka: Centar za kulturni i socijalni popravak.

Dušanić, S. (2007b). Psihološka istraživanja religioznosti. Banja Luka: Filozofski fakultet

Dušanić, S. (2007c). Kada religija postaje dio problema. U G. Z. Golubović (Ur.), Homoreligiosus: Psihološko-teološki dijalog (str 68-102). Niš: Filozofski fakultet.

Dušanić, S., Došen, G. N., \& Tanasić, J. (2015). Post-critical belief scale examination in the context of relations with ethnocentrism and life satisfaction. Paper presented at $X I$ International conference Days of Applied Psychology (Abstract book). Niš: Faculty of Philosophy.

Glock, C. Y., \& Stark, R. (1968). American piety: The nature of religious commitment (Vol. 1). Berkley, CA: University of California Press.

Hill, P. C., \& Hood, R. W. (Eds.). (1999). Measures of religiosity. Birmingham, AL: Religious Education Press.

Hogg, M. A., Adelman, J. R., \& Blagg, R. D. (2010). Religion in the face of uncertainty: An uncertainty-identity theory account of religiousness. Personality and social psychology review, 14(1), 72-83.

Hyde, K. E. (1990). Religion in childhood and adolescence: A comprehensive review of the research. Birmingham, AL: Religious Education Press. 
Kaufmann, E. (2012). Primordialists and constructionists: a typology of theories of religion. Religion, Brain \& Behavior, 2(2), 140-160.

Koenig, H. G., McCullough, M., \& Larson, D. B. (2001). Religion and health: A century of research reviewed. New York: Oxford University Press.

Milošević-Đorđević, J. S. (2005). Nacionalni identitet: psihološka analiza naučnih i laičkih shvatanja. Beograd: Filozofski fakultet.

Pantić, D. (1988). Klasična i svetovna religioznost. Beograd: Institut društvenih nauka.

Popadić, D. (1995). Uzrasne i generacijske razlike u preferenciji životnih ciljeva. Psihološka istraživanja, 7, 71-88.

Runić, N. (2011). Relacije između multidimenzionalnih konstrukata religioznosti i etničke vezanosti (Neobjavljena master teza). Filozofski fakultet, Banja Luka.

Subotić, S., Knežević, I. i Dimitrijević, S. (2014). Postoji li veza između socijalno poželjnog odgovaranja i religijskih orijentacija? Otvoreni dani psihologije Banja Luka (Knjiga rezimea). Banja Luka: Filozofski fakultet.

Turjačanin, V., Majstorović, D., Turjačanin, M., Milosavljević, B., Dušanić, S. i Lovrić, S. (2010). Tolerancija u društvu. Banjaluka: Centar za kulturni i socijalni popravak.

Tešanović, J. (2012). Socio-psihološki korelati posjećivanja crkve kod adolescenata. U J. Kulenović-Đapo et al. (Ur.). Zbornik radova Drugog Kongresa psihologa BiH sa međunarodnim učešćem, 211-237.

Turjačanin, V. (2015). Socijalna psihologija etničkog identiteta. Banja Luka: Filozofski fakultet.

Vrcan, S. (1986). Od krize religije $k$ religiji krize: prilog raspravi o religiji u uvjetima suvremene krize. Zagreb: Školska knjiga.

\title{
Srđan Dušanić ${ }^{2}$
}

University of Banja Luka

Faculty of Philosophy

Department of Psychology

Banja Luka, Republic of Srpska, Bosnia and Herzegovina

\section{RELIGIOUS IDENTITY OF YOUTH IN REPUBLIKA SRPSKA: IMPORTANCE, PERCEPTION AND MEASUREMENT}

\begin{abstract}
This research attempts investigate the relation of youth towards religious identity using the more comprehensive and precise methods than before. This objective is presented as the following research tasks: 1) Question demonstration of the concrete religious manifestations, not only general religious beliefs; 2) Examine perception of the religious identity; 3) Examine relations between different dimensions of religiosity and religious intolerance 4) Examine the importance of religiosity in the context of other values' orientations. The conducted research is the quantitative one, using the sample
\end{abstract}

\footnotetext{
${ }^{2}$ Corresponding author email: srdjan.dusanic@ff.unibl.org
} 
of 377 young persons (61.3\% female, $38.7 \%$ male) from Republika Srpska, the average age of 19 years. The questionnaire contained questions on the general and specific religious manifestations, perception of religious identities, multidimensional scale of religiosity, and scale of preference of lifestyles examining the importance of religiosity in the wider context of values. The results show that majority of youth state they are religious (71\%), but specific religious activities are less manifested. $92 \%$ respondents stated the religious identity as important, and expressed it through marking religious holidays, christenings, and leading life in according to the religious principles. The general belief is that religious identity is acquired on birth or very early however it can be changed during the course of life showing the complexity of socializing and primordial approach to the issue of identity. The coherency of the stated results is disturbed by the fact that religiosity is ranked as the eight on the scale of importance in the context of different life styles. Religions intolerance is correlating with the dimension of religious beliefs, religious practice and traditional and institutional religiosity. The results are discussed in the context of the relative theories and other similar researches.

Keywords: religious identity, religious dimensions, intolerance

Primljeno: 09. 06. 2019.

Primljena korekcija: 18. 09. 2019.

Prihvaćeno za objavljivanje: 23. 09. 2019. 


\section{PRILOG 1: FAKTORSKA ANALIZA SKALE RELIGIOZNOSTI}

\begin{tabular}{ccccc}
\hline Komponente & $\begin{array}{c}\text { Svojstvene } \\
\text { vrednosti }\end{array}$ & $\begin{array}{c}\text { Procenat } \\
\text { objašnjene } \\
\text { varijanse }\end{array}$ & $\begin{array}{c}\text { Kumulativni } \\
\text { procenat } \\
\text { objašnjene } \\
\text { varijanse }\end{array}$ & $\begin{array}{c}\text { Suma rotacije } \\
\text { kvadiranih } \\
\text { opterećenja }\end{array}$ \\
\hline 1 & 10.047 & 27.908 & 27.908 & 6.524 \\
2 & 3.117 & 8.658 & 36.566 & 6.803 \\
3 & 2.532 & 7.033 & 43.599 & 6.616 \\
4 & 2.288 & 6.355 & 49.954 & 6.486 \\
5 & 1.656 & 4.600 & 54.554 & 3.194 \\
6 & 1.313 & 3.646 & 58.201 & 4.735 \\
7 & 1.221 & 3.391 & 61.592 & 2.291 \\
8 & 1.035 & 2.875 & 64.467 & \\
9 & .899 & 2.497 & 66.964 & \\
\hline
\end{tabular}

Napomena. Metod ekstrakcije: Analiza glavnih komponenti (PCA).

\begin{tabular}{|c|c|c|c|c|c|c|c|}
\hline \multicolumn{8}{|c|}{ Matrica strukture (Pattern Matrix) } \\
\hline & \multicolumn{7}{|c|}{ Komponente } \\
\hline & 1 & 2 & 3 & 4 & 5 & 6 & 7 \\
\hline \multicolumn{8}{|l|}{ Imao/la sam doživljaj } \\
\hline jedinstva između mene i & .849 & & & & & & \\
\hline \multicolumn{8}{|l|}{ Boga } \\
\hline \multicolumn{8}{|l|}{ Imao/la sam doživljaj } \\
\hline Božjeg prisustva i njegove & .805 & & & & & & \\
\hline \multicolumn{8}{|l|}{ energije } \\
\hline \multicolumn{8}{|l|}{ Imao/la sam unutrašnji } \\
\hline mistični doživljaj koji se ne & .751 & & & & & & \\
\hline \multicolumn{8}{|l|}{ može opisati riječima } \\
\hline \multicolumn{8}{|l|}{ Imao/la sam osjećaj da } \\
\hline \multirow{2}{*}{\multicolumn{8}{|c|}{$\begin{array}{l}\text { ponekad kao da Bog ili } \\
\text { sveti duh nadahnjuju ono }\end{array}$}} \\
\hline & .120 & & & & & & \\
\hline \multicolumn{8}{|l|}{ što pričam. } \\
\hline \multicolumn{8}{|l|}{ Ponekad kao da osjećam } \\
\hline šta Bog želi od mene da & .698 & & & & & & \\
\hline \multicolumn{8}{|l|}{ učinim. } \\
\hline \multicolumn{8}{|l|}{ Imao/la sam doživljaj } \\
\hline neopisivog unutrašnjeg & .688 & & & & & & \\
\hline blaženstva i spokojstva & & & & & & & \\
\hline
\end{tabular}


Imao/la sam doživljaj da

sve što postoji je dio jedne $\quad .638$

skladne cjeline.

Vjerujem da Bog postoji. $\quad .883$

Isus Hristos je Sin Božiji. $\quad .875$

U vjerskim spisima

(npr. Biblija, Kur'an) je

predočena riječ Božija.

Vjerujem da postoje Božija

čuda.

Vjerujem da ima života

poslije smrti.

Vjernik sam jer tako

potvrđujem i štitim i svoj

nacionalni identitet.

Treba biti vjernik jer tako

odajemo poštovanje našim

precima.

Vjerske institucije (crkve,

džamije) su neophodne da

bi čovjek pronašao Boga.

Izuzetno poštujem vjerske

službenike (sveštenike) i

vjerujem im.

Pravi vjernik treba da

poštuje propisane vjerske

praznike.

Postim u skladu s vjerskim

propisima

Moj odnos prema vjeri i

Bogu, utiče da činim dobro

i onima koji me mrze.

Moj odnos prema vjeri

i Bogu, utiče da uvijek

opraštam ljudima kada mi

urade nešto loše. 
Moj odnos prema vjeri

i Bogu, utiče da u

svakodnevnom životu

volim druge kao i samog

sebe.

Molim se i za one koji me

vrijeđaju i ugrožavaju.

Odraz moje vjere u Boga je

da pomažem i ljudima koji

mi nisu ništa.

Ne bih volio/la da moja

djeca idu u razred sa

djecom drugih religija.

Dobro je da u našoj državi

žive različite religije.*

Ponekad poželim da

uvrijedim pripadnike

drugih religija.

Ne vjerujem mnogo

pripadnicima drugih

religija.

Više religija u jednom

društvu uvijek donosi

probleme.

Koliko često čitaš vjersku

literaturu?

Koliko često čitaš vjerske

spise (npr. Biblija, Kur'an

i sl.)

Koliko često pričaš o vjeri

sa članovima porodice,

prijateljima, komšijama ili

kolegama?

Koliko često ideš

u bogomolju da bi

prisustvovao/la vjerskim

obredima? 
Koliko ukupno ima

jevanđelja?

Koji narod u starom zavjetu

je prozvan "'izabranim

narodom"?

Kako se zvao Isusov

zemaljski otac?

Ko među navedenim NIJE

bio član 12 Hristovih

apostola?

Napomena. Metod ekstrakcije (prikazana zasićenja veća od .30.): Analiza glavnih komponenti (PCA); Metod rotacije: Promax sa Kajzer normalizacijom. Komponenta 1: Religiozno iskustvo; Komponenta 2: Religiozna uvjerenja; Komponenta 3: Tradicionalno-institucionalna religioznost; Komponenta 4: Altruistična religioznost; Komponenta 5: Religiozna netolerancija; Komponenta 6: Religiozne aktinvosti/praksa; Komponenta 7: Religiozno znanje.

\section{PRILOG 2: DIMENZIJE RELIGIOZNOSTI S OBZIROM NA POL}

\begin{tabular}{llccccc}
\hline Dimenzije & Pol & $N$ & $M$ & $S D$ & $t$ & $p$ \\
\hline \multirow{2}{*}{ Religiozna uvjerenja } & ženski pol & 225 & 3.61 & .61 & .676 & .500 \\
& muški pol & 145 & 3.56 & .72 & & \\
Religiozne aktivnosti & ženski pol & 229 & 2.51 & .71 & 1.095 & .274 \\
& muški pol & 145 & 2.43 & .74 & & \\
Religiozno iskustvo & ženski pol & 221 & 2.60 & .83 & -1.326 & .186 \\
& muški pol & 141 & 2.72 & .89 & & \\
Religiozno znanje & ženski pol & 200 & .66 & .32 & .748 & .455 \\
\multirow{2}{*}{ Religiozna netolerancija } & muški pol & 126 & .63 & .37 & & \\
Tradicionalno- & ženski pol & 229 & 2.34 & .76 & -3.371 & .001 \\
institucionalna & muški pol & 142 & 2.65 & .97 & & \\
religioznost & ženski pol & 225 & 3.26 & .89 & & \\
\multirow{2}{*}{ Altruistična religioznost } & muški pol & 143 & 3.32 & .93 & -.571 & .569 \\
& ženski pol & 223 & 3.27 & 1.04 & & \\
\hline
\end{tabular}

